Г. Цапок. У другій редакції опера «Наймичка» поставлена у Донецьку в 1961 році.

Жіночі арії з опер Михайла Вериківського у трактовці Зої Христич, Зої Гайдай, Марії Литвиненко-Вольгемут та Лариси Руденко - безцінний скарб української вокальної культури.

Органічне злиття музики і поезії, правдиві сценічні образи та картини народного побуту обумовлюють унікальну цінність творів М. Веріковського на шевченківські сюжети.

Оперні шедеври композитора мають унікальну вокально-виконавську традицію та непересічну сценічну інтерпретацію, яка потребує наукового осмислення.

\title{
Література:
}

1. Бентя Ю. В. Особовий фонд композитора Михайла Вериківського (з нових надходжень ЦДАМЛМ України). Архіви України. 2012. № 4 (280). C. 76-87

2. Герасимова-Персидська Н. Образи Шевченка в оперній творчості М. Веріковського. Шевченко і музика : зб. ст. К., 1966. С. 65-77.

3. Толошняк Н. Камерна опера М. Вериківського (до 90-річчя від дня народження композитора). Музика. 1986. № 6. С. 20-21.

4. Шольп О. Лірика Шевченка і «Сотник» М. І. Вериківського. Украӥнське музикознавство. 1968. Вип. 3. С. 104-112.

DOI https://doi.org/10.30525/978-9934-26-004-9-122

\section{ТЕМА ГОЛОДОМОРУ У ХОРОВИХ ТВОРАХ УКРАЇНСЬКИХ КОМПОЗИТОРІВ ХХ-ХХІ СТОЛІТЬ}

\author{
Василенко О. В. \\ кандидат мистеитвознавства, доцент, \\ доцент кафедри історії музики \\ факультету виконавського мистецтвва та музикознавства \\ Київська муніџипальна академія музики імені Р. М. Глієра \\ м. Київ, Україна
}

Голодомор - одна із трагічних сторінок української історії $30-$ х років минулого століття. Лише в епоху Незалежності зазначена тема актуалізується і стає предметом творчості українських композиторів. У 90-х роках XX ст., за підтримки культурних діячів діаспори тема Голодомору вкорінюється у простір вітчизняних та міжнародних фестивалів сучасної музики, таких, як «Київ Музик Фест», «Контрасти», 204 
«Віртуози Львова», озвучується у творах різноманітних «музичних панорам» крупних міст України.

Трагічна тема штучного голоду широко репрезентована у різних видах мистецтва (кіно, література, живопис, музика), але вона майже не досліджена мистецтвозавцями. Відмітимо лише декілька музикознавчих робіт: Ганна Карась аналізує оперу Вірко Балея «Червона земля. Голод» [2]; Зоя Лаврова розглядає трагічну образність ораторії про Голодомор Юрія Ланюка «Скорботна мати»[3].

Музика, що втілює трагедію Голодомору, написана знаними українськими композиторами світового рівня, серед яких: Вірко Балей, Левко Колодуб, Генадій Ляшенко, Валентин Бібік, Леся Дичко, Генадій Сасько, Юрій Ланюк, Олег Кива, Свген Станкович, Мирослав Скорик, Іван Карабиць, Ігорь Щербаков, Олександр Яковчук, Богдана Фроляк, Віктор Степурко та багато інших.

Тема Голодомору втілюється у різних жанрах, вона репрезентована в оперно-театральній, симфонічній, камерно-ораторіальній та вокальнохоровій музиці. Серед творів останньої жанрової групи - реквієми, панахиди, кантати та окремі хори. Кожен вокально-хоровий опус, що розкриває трагічну тему штучного голоду, спирається на певну ускладнену жанрово-композиційну музичну модель. Наприклад, відмічаємо подібне у наступних творах, де поєднано риси: хорового концерту та думи (у творі Г. Саська «Дума про 33-й»), симфонії та реквієму (у творі О. Яковчука «Тридцять третій»). Хорова музика на тему Голодомору також вдало синтезує різні типи культових поминальних жанрів («Stabat mater» та католицький «Requiem»), поєднує композиційні риси панахиди та симфонізованої програмності (наприклад, православного поминального жанру та історичної хроніки як у «Панахиді» С. Станковича).

У 1993 році написана «Дума про тридцять третій» для мішаного хору та солістів Геннадія Саська на вірші Миколи Ткача. У назві твору закарбований основний жанр кобзарської музики - дума. Образ чорного крюка, типовий для народних дум, символізує тут радянське нашестя, знак біди, зловісний символ війни, голоду і смерті цілого народу, зокрема, і кобзарської культури України. Хорова дума Геннадія Саська вирішена у традиціях поминальних співів України - панахиди. Саме так звучить драматична розповідь про загиблих, розстріляних синів рідної землі, кобзарів, у сольній партії баритона. В музиці відтворюється стилістика кобзарського інструментального награвання - супроводу думи (доручена партії хору). Своєрідна Дума-Реквієм за загиблими у Голодоморі 33-го року завершується темою-алюзією траурного маршу 3 
сонати № 2 Фрідеріка Шопена. Нею озвучується текст: «Розтривожте пам'ять! Оживите словом!»

Реквієм «Стражденна мати» Гайденко Анатолія також написаний у 1993 році. Це хоровий твір синтетичного жанру на текст В. Забаштанського для мішаного хору а cappella, присвячений 70-річчю трагедії 30-х років минулого століття. Характерною ознакою реквієму $\epsilon$ використання віршів українського поета та культової латини «Stabat mater». Чинником, що єднає обидві католицькі концепції («Stabat mater» та «Requiem») є українська музична фольклорна архаїка: композитор використовує стилістику українського поховального голосіння, яку відтворюють окремі хорові партії.

Майже усі видатні вокально-хорові твори на тему Голодомору мають ускладнену жанрову модель та відповідну музичну стилістику. Вкажемо на видатні твори цієї жанрово-стильової лакуни української музики: Іван Карабиць, кантата «Молитва Катерини» на вірші Катерини Мотрич для оповідача (декламаторки), дитячого хору та симфонічного оркестру; Козаренко Олександр, «Український реквієм. Лемківській» для солістів, хору i двох оркестрів (народного та симфонічного); Ланюк Юрій, Ораторія «Скорбна мати» на текст Павла Тичини; Матвійчук Людмила, «Голод», кантата для мішаного хору на вірші Олександра Олеся; Птушкін Володимир, «Український реквієм пам'яті жертв трагедії 20-го сторіччя, на текст лауреата Національної премії ім. Т. Г. Шевченка Степана Сапеляка; Скорик Мирослав, «Панахіда» для солістів і мішаного хору без супроводу (в першій редакції 1998 року «Заупокійна»); Станкович Євген «Панахида за померлими 3 голоду» («Жертвам голодомору») для солістів, двох мішаних хорів, читця та симфонічного оркестру, слова Дмитра Павличка; Щербаков Ігор, «Сон» духовний концерт пам'яті жертв Голодомору на вірші Юрія Плаксюка для читця, тенору, органу, хору та симфонічного оркестру; симфонія-реквієм «Тридцять третій» Олександра Яковчука на вірші Олександра Юхимовича.

Окремо зазначимо трагічну хорову мініатюру Лесі Дичко «Плач. Голодомор в Україні 1933 р.» (для мішаного хору) на вірші В. Коломійця яка за масштабним задумом та високим ступенем узагальнення не поступається монументальним творам.

Твір Лесі Дичко присвячено Квітці та Михайлові Кондрацьким. Одночастинна композиція вільної побудови, що об'єднана фантасмагоричною темою трагічного характеру, звучить у повільному темпі та на піаніссімо. Першій епізод твору використовує хоровий прийом mormorando (спів із закритим ротом), що звучить неймовірно 
виразно та проникливо. Особливий прийом звукобудування 3 акцентом та контрастом динаміки співу на кожному довгому звуці влучно передає тілесний та психологічний стан жінки: схвильоване биття серця, стогін, плач безпорадної матері. Другий епізод - соло тенору, де звучить сумна розповідь-запитання про трагедію голодної смерті дитини та матері, трагедії, яку не подолати: «Хто там б’ється о груди знечулені?». Хорову лінію партій сопрано (супровід зазначеного соло) побудовано на паралельному русі терціями у високому регістрі. Вона звучить неймовірно колористично та ілюструє поетичні рядки: це й влучна імітація вітру, «що завиває»; ковзаючи хроматизми - як «змї̈, що овівають нещасну душу» жінки на порозі смерті, згасання-марення. Третій епізод має хоральну фактуру, відтворює церковну стилістику співу: «Божа Мати почула...Божа Матір поглянула... 3 хати дибця....) . Надалі розповідається про смерть дитини та жах Божої мати, чий іконописний лик «бачить», відчуває ці жахи земного пекла, іiі скорботу. Заключне соло сопрано побудовано на плачових інтонаціях у високому регістрі. Кода містить музично-стильову алюзію кобзарського награвання, це - згадка про кобзарів, хранителів історії Голодомору та правди народної. Кульмінацію зосереджено саме тут. Поетичний «сюжет» стає більш трагічним: «Божа Матір дитину у гробик положила». Як наслідок - хорове інтонування нагадує плач, стогін, зойк болю.

Хорова мініатюра Лесі Дичко - видатної представниці української композиторської школи сучасності, пронизливо та 3 глибоким внутрішнім болем малює хоровими засобами страшну картину Голоду 1933 року, узагальнює трагічну долю жінок тогочасної України. Як і у реквіємі «Стражденна мати» А. Гайденка, у кантаті I. Карабиця «Молитва Катерини», ораторії Ю. Ланюка «Скорбна мати», у хорі «Плач» Л. Дичко образ матері-Богородиці прирівнює 3 образами стражденних українських жінок-матерів. Їх трагічна доля узагальнюється та відчутно символізується, відбиває долю рідної країни. Подібне тлумачення має глибоке коріння у культурі. Узагальнений образ жінки у вокально-хорових творах на тему Голодомору, на наш погляд, відповідає архетипу Ославленої Мадонни, якій в українській культурі глибоко досліджений В. Драганчук. Науковиця зазначає: «Національне мислення як міфотворення функціонує на основі архетипів, які $є$ знаками укладеної упродовж тисячоліть кодової системи і реалізують ментальні програми спільноти. У процесі тривалого функціонування в інформаційному середовищі, несучи стійке семантичне навантаження, той чи інший архетип набуває ролі могутнього психічного прототипу-символу <..>.У таких «первинних моделях» згущені колективні уявлення про ті чи інші 
рольові моделі - Матері та Великої Матері, Батька та Мудрого Старого, Героя, Дівчини та ін. [1, с. 65]. В хоровій творчості українських композиторів на тему Голодомору втілено трагічний образ знедоленої української жінки. Він є одним із ключових українських образів, що відноситься до інваріантного архетипу Жінки. Один з них - символархетип Ославленої Мадонни, оспіваний у поетичній i живописній творчості іще Тарасом Шевченком. Функціонуючи у національній свідомості культурних діячів XIX-XXI століть, цей символ-архетип знайшов широке відображення у музичному дискурсі в деяких жіночих образах творів Лисенка, Аркаса, Вериківського, Кирейка, Дичко, Карабиця, Сильвестрова та інших. Більше того, символ-архетип Жінки став символом не-долі усієї України. Музика українських композиторів втілює різні відтінки жіночого образу: від трагедійного - до просвітленомолитовного у часопросторі «і мертвих, і живих, і ненародженних...».

Вітчизняні композитори XXI ст. вважають, що шлях просвітлення долі нашої країни почнеться 3 відповідного напряму трансформації образу жінки, що символізує Україну. Вона вийде зі скривдженого кола власної не-долі і буде здатною до сприйняття Божої ласки [1, с. 72]. Наприклад, видатний композитор сучасності, Валентин Сильвестров переводить цей архетип із минулого стану «покривдженості» і підносить до Божественної висоти музичний образ Жінки-України у величі власної метафоричної музики.

\section{Література:}

1. Драганчук В. М. Архетип Ославленої Мадонни у музичному дискурсі: кордоцентризм української не-долі. Актуальні проблеми мистецької практики і мистеитвознавчої науки. 2015. Вип. 7.С. 65-75.

2. Карась Г. В. Тема голодомору 1932-1933 рр. в Україні в контексті музики постмодерну: на прикладі опери Вірко Балея. Культура $i$ сучасність : альманах. К. : Міленіум, 2013. № 2. С. 102-107.

3. Лаврова Зоя. Драматургія ораторії Ю. Ланюка «Скорбна мати». Київське музикознавство. Культурологія та мистеитвознавство. Збірка статей. Вип. 47. К. : КІМ ім. Р.М. Глієра, 2013. С.161-170. 